\title{
LIVER
}

\section{High frequency of functional anti-YMDD and -mutant cytotoxic T lymphocytes after in vitro expansion correlates with successful response to lamivudine therapy for chronic hepatitis B}

\author{
C-L Lin, S-L Tsai, T-H Lee, R-N Chien, S-K Liao, Y-F Liaw
}

Gut 2005;54:152-161. doi: 10.1136/gut.2003.032920

Background: Many determinants for a sustained response to lamivudine therapy have been reported but the role of $\mathrm{T}$ cell responsiveness remains unclear. The finding that tyrosine-methionine-aspartate-aspartate (YMDD) motif of the reverse transcriptase domain of hepatitis B virus (HBV) DNA polymerase carries a HLA-A2 restricted cytotoxic T lymphocyte (CTL) epitope makes quantitative measurement of the numbers of peptide specific CTLs feasible using MHC tetramer-peptide complex staining.

See end of article for authors' affiliations

Correspondence to: Professor S-L Tsai, Liver Research Unit, Department of Medical Research, ChiMei Foundation Medical Centre, Tainan, Taiwan, 901, Chung-Hwa Rd, Young-Kang City, TainanHsien,710 Taiwan; sltsai@ mail.chimei.org.tw

Revised version received 25 January 2004

Accepted for publication 30 March 2004 Aim: To investigate the correlation between anti-YMDD motif CTL activity and the efficacy of lamivudine therapy in HLA-A2 positive patients with chronic hepatitis $B(C H-B)$.

Methods: The function and phenotype of peptide and interleukin 2 expanded peripheral blood mononuclear cells were quantified by cell lytic assay and immunocytochemical analysis by staining with HLA-A2-peptide tetramer complexes.

Results: After in vitro expansion, sustained responders had more potent CTL responses against YMDD, YVDD, and YIDD, as well as other epitopes on HBV antigens than non-responders. The frequency of YMDD/YVDD/YIDD motif specific CTLs increased significantly with an effective cell lytic function during and after therapy in sustained responders but not in non-responders. YMDD specific CTLs cross reacted with YIDD and YVDD mutant epitopes, and shared T cell receptor gene usages with YIDD and YVDD specific CTLs.

Conclusions: Sustained responders, at least HLA-A2 patients, elicited a more potent CTL immunity against YMDD and its mutants. YMDD specific CTLs are cross reactive with YVDD and YIDD mutant epitopes, which may further contribute to immune clearance of the mutant viruses and a successful response to lamivudine therapy in $\mathrm{CH}-\mathrm{B}$ patients. amivudine, (-)-2', 3'-dideoxy-3'-thiacytidine (3TC), has become the main therapeutic option for treating hepatitis -B virus (HBV) infection. ${ }^{1-5}$ Its antiviral effects against HBV have been established both in vitro and in vivo. ${ }^{6-8}$ Results from clinical trials revealed that lamivudine is effective in reducing HBV replication and preventing the progression of chronic liver disease. ${ }^{45}{ }^{10}$ Complete suppression of viral replication, as determined by negativity for serum HBV DNA, may be achieved in most patients; however, clearance of hepatitis B e antigen (HBeAg) with antibody (anti-HBe) seroconversion was seen in only a minority of patients. ${ }^{135}$ In Asian patients, HBeAg seroconversion with loss of HBV DNA after lamivudine therapy occurred in $16 \%$, $27 \%, 40 \%$, and $47 \%$ of patients after $1,2,3$, and 4 years of treatment, respectively. ${ }^{14910}$ Resistance to lamivudine therapy also increased in frequency with continuation of therapy, with rates being estimated as $17 \%, 40 \%, 55 \%$, and $67 \%$ after $1,2,3$, and 4 years of therapy, respectively. ${ }^{10}$

The genome of the lamivudine resistant virus has been mapped to mutations in the tyrosine-methionine-aspartateaspartate (YMDD) motif of the reverse transcriptase (rt) domain of HBV DNA polymerase. Specifically, methionine 552 was mutated to isoleucine or valine (rtM552I/V) in patients with rebound viraemia. ${ }^{11}{ }^{12}$ The appearance of lamivudine resistant $\mathrm{HBV}$ is a major clinical concern as it has been associated with a decreased rate of HBeAg seroconversion and deterioration of liver histology as well as clinical outcome. ${ }^{13-15}$ Mutations in the sequence of highly conserved YMDD motif, such as YIDD and YVDD, may also develop during lamivudine therapy in both immunocompetent hosts and immunosuppressed patients after liver transplantation. ${ }^{11}{ }^{16}{ }^{17}$ Moreover, lamivudine is an rt inhibitor, ${ }^{218}$ which has little effect on the episomal template of HBV (that is, closed circular DNA), a source of viral replication. The mechanism of successful lamivudine therapy therefore remains to be elucidated. ${ }^{219}$ Several parameters such as patients with genotype $B$, age less than 36 years, and additional lamivudine treatment over eight months have been shown to be the major determinants for a sustained response to lamivudine therapy ${ }^{20}$; however, the role of cytotoxic $\mathrm{T}$ lymphocyte (CTL) responses has yet to be determined. Rehermann and colleagues ${ }^{21}$ have shown that the nonapeptide YMDDVVLGA (amino acid residues 551559 ) on the YMDD motif, superimposing with the catalytic

\footnotetext{
Abbreviations: ACRS, amplification created restriction site; ALT, alanine aminotransferase; AV, T cell receptor $\alpha$ variable; BV, T cell receptor $\beta$ variable; $B-L C L, H L A-A 2$ positive Epstein-Barr virus transformed B cell line; $\mathrm{CH}-\mathrm{B}$, chronic hepatitis $\mathrm{B} ; \mathrm{CTL}$, cytotoxic $\mathrm{T}$ lymphocyte; $C R$, complete response; $C R I-p, C T L$ response index of the peptide; $E / T$, effector/target cell; FACS, fluorescence activated cell sorter; $\mathrm{HBV}$, hepatitis $B$ virus; $\mathrm{HCV}$, hepatitis $C$ virus; $H D V$, hepatitis delta virus; $\mathrm{HBCAg}$, hepatitis $\mathrm{B}$ core antigen; $\mathrm{HBeAg}$, hepatitis $\mathrm{B}$ e antigen; $\mathrm{HIV}$, human immunodeficiency virus; IL-2, interleukin 2; NR, nonresponse; PBMCs, peripheral blood mononuclear cells; PCR, polymerase chain reaction; PHA, phytohaemagglutinin; PR, partial response; rt, reverse transcriptase; TCR, T cell receptor; 3TC, (-)-2' 3'-dideoxy- 3'thiacytidine (lamivudine); YMDD motif, tyrosine-methionine-aspartateaspartate motif
} 
site of the HBV DNA polymerase, ${ }^{2}$ is a HLA-A2 restricted CTL epitope. Quantitative measurement of the numbers of peptide specific CTLs is thus feasible by staining MHC tetramerpeptide complexes in HLA-A2 positive patients with chronic hepatitis B (CH-B). We therefore employed both phenotypic and functional immunological assays to assess the correlation between anti-YMDD motif CTL activity and the efficacy of lamivudine therapy in HLA-A2 patients with $\mathrm{CH}-\mathrm{B}$.

\section{MATERIALS AND METHODS Study subjects}

Fourteen HLA-A2 (+) adults with $\mathrm{CH}-\mathrm{B}$ (table 1) were enrolled in the present study and were evaluated from July 1999 to July 2001. Eleven non-HLA-A2 patients (data not shown) were also studied as control patients during the same period. Before lamivudine treatment, all patients met the following criteria: presence of hepatitis B surface antigen (HBsAg) and HBeAg in serum for at least six months; raised serum alanine aminotransferase (ALT) levels; liver biopsy taken within three months of enrolment showing $\mathrm{CH}-\mathrm{B}$ with hepatocyte expression of hepatitis B core antigen (HBcAg); seropositivity for HBV DNA (Digene HBV Test, Hybrid Capture II; Digene Corp., Maryland, USA) on at least two occasions one month apart before entry; and undetectable YMDD mutants in serum by amplification created restriction site (ACRS) analysis, as described previously. ${ }^{14}$ The sensitivity of ACRS in detecting YMDD mutants approximates $1 \%$ of the viral population. Concurrent hepatitis $\mathrm{C}$ virus (HCV) or hepatitis delta virus (HDV) infections were excluded, and none had human immunodeficiency virus (HIV) infection. HBsAg, anti-HBs, total and IgM anti-HBc, HBeAg, anti-HBe, anti-HDV, anti-HCV, anti-HIV-1, and anti-HIV-2 were determined by commercially available ELISA kits (Abbott
Laboratories, North Chicago, Illinois, USA; Ortho Diagnostic Systems, Raritan, New Jersey, USA; Sanofi Diagnostic Pasteur, Marnes-la Coquette, France).

Oral lamivudine (Zeffix; GlaxoWellcome, Greenford, UK) $100 \mathrm{mg}$ per day was administered for more than nine months. Complete response (CR) to treatment was defined as sustained HBeAg seroconversion to anti-HBe in association with disappearance of serum HBV DNA and normalisation of serum ALT levels for at least 12 months after cessation of treatment. Cases with transient normalisation of serum ALT levels followed by a relapse either within 12 months after cessation or during lamivudine therapy were defined as partial responders (PR). Non-response (NR) was defined as lack of either a biochemical or virological response to therapy. Routine follow up studies included clinical assessment, conventional liver biochemical tests, and serological markers of hepatitis viruses. All patients were followed for more 12 months after the end of lamivudine therapy and completion of immunological assays. Immunological assessments, including modified CTL response index of the peptide (CRI-p) culture, fluorescence activated cell sorter (FACS) analysis, tetramer staining and cell sorting, T cell receptor (TCR) gene analysis, and CTL killing assays were performed in consecutive patients on a volunteer basis because these experiments needed extensive blood sampling. HLA typing was performed using standard serological techniques (Terasaki HLA Tissue Typing Trays; One Lambda, Inc., Canoga Park, California, USA). Those with the HLA-A2 haplotype were subsequently confirmed to have HLA-A2.1 allele by DNA typing (Micro-SSP, HLA DNA Typing Trays, One Lambda). Patients other than HLA-A2 were also included as mutual controls to ensure the specificity of the tetramer assay and peptide specific CTL assay. Immunological

\begin{tabular}{|c|c|c|c|c|c|c|c|c|c|}
\hline \multirow[b]{2}{*}{ Patient' } & \multirow{2}{*}{$\begin{array}{l}\text { Age } \\
\text { (y) }\end{array}$} & \multirow[b]{2}{*}{ Sex } & \multirow{2}{*}{$\begin{array}{l}\text { Peak ALT } \\
\text { value } † \\
\text { (U/I) }\end{array}$} & \multirow{2}{*}{$\begin{array}{l}\text { Clinical } \\
\text { diagnosis }\end{array}$} & \multicolumn{4}{|c|}{$\begin{array}{l}\text { Percentage of tetramer staining } \\
C D 8+T \text { cells after in vitro expansion }\end{array}$} & \multirow[b]{2}{*}{ Outcome } \\
\hline & & & & & Core $18-27$ & YMDD & YVDD & YIDD & \\
\hline 1 & $32(\mathrm{~A} 2+)$ & $M$ & 280 & $\mathrm{CH}-\mathrm{B}$ & $\begin{array}{l}0.3 \ddagger \\
0.4 \S\end{array}$ & $\begin{array}{l}0.4 \\
0.3\end{array}$ & $\begin{array}{l}0.1 \\
0.1\end{array}$ & $\begin{array}{l}0.0 \\
0.1\end{array}$ & NR \\
\hline 2 & $22(\mathrm{~A} 2+)$ & $\mathrm{F}$ & 376 & $\mathrm{CH}-\mathrm{B}+\mathrm{AE}$ & $\begin{array}{l}1.0 \\
1.2\end{array}$ & $\begin{array}{l}0.8 \\
1.1\end{array}$ & $\begin{array}{l}1.5 \\
2.1\end{array}$ & $\begin{array}{l}2.9 \\
4.0\end{array}$ & $C R$ \\
\hline 3 & $38(\mathrm{~A} 2+)$ & $M$ & 306 & $\mathrm{CH}-\mathrm{B}$ & $\begin{array}{l}\text { nd } \\
3.3\end{array}$ & $\begin{array}{l}\text { nd } \\
2.1\end{array}$ & $\begin{array}{l}\text { nd } \\
2.8\end{array}$ & $\begin{array}{l}\text { nd } \\
2.2\end{array}$ & $C R$ \\
\hline 4 & $46(\mathrm{~A} 2+)$ & M & 50 & CH-B & $\begin{array}{l}\text { nd } \\
0.3\end{array}$ & $\begin{array}{l}\text { nd } \\
0.1\end{array}$ & $\begin{array}{l}\text { nd } \\
0.1\end{array}$ & $\begin{array}{l}\text { nd } \\
0.1\end{array}$ & NR \\
\hline 5 & $46(\mathrm{~A} 2+)$ & M & 72 & CH-B & $\begin{array}{l}\text { nd } \\
1.5\end{array}$ & $\begin{array}{l}\text { nd } \\
2.0\end{array}$ & $\begin{array}{l}\text { nd } \\
1.9\end{array}$ & $\begin{array}{l}\text { nd } \\
1.7\end{array}$ & $C R$ \\
\hline 6 & $40(\mathrm{~A} 2+)$ & M & 931 & $\mathrm{CH}-\mathrm{B}+\mathrm{AE}$ & $\begin{array}{l}0.3 \\
0.5\end{array}$ & $\begin{array}{l}0.4 \\
0.7\end{array}$ & $\begin{array}{l}0.3 \\
0.5\end{array}$ & $\begin{array}{l}0.1 \\
0.1\end{array}$ & PR \\
\hline 7 & $33(\mathrm{~A} 2+)$ & $\mathrm{F}$ & 111 & $\mathrm{CH}-\mathrm{B}$ & $\begin{array}{l}\text { nd } \\
0.2\end{array}$ & $\begin{array}{l}\text { nd } \\
0.2\end{array}$ & $\begin{array}{l}\text { nd } \\
0.1\end{array}$ & $\begin{array}{l}\text { nd } \\
0.1\end{array}$ & NR \\
\hline 8 & 31 (A2+) & M & 208 & $\mathrm{CH}-\mathrm{B}$ & $\begin{array}{l}1.7 \\
1.9\end{array}$ & $\begin{array}{l}1.0 \\
2.0\end{array}$ & $\begin{array}{l}2.0 \\
2.7\end{array}$ & $\begin{array}{l}1.9 \\
3.0\end{array}$ & $C R$ \\
\hline 9 & $28(\mathrm{~A} 2+)$ & $\mathrm{F}$ & 527 & $\mathrm{CH}-\mathrm{B}$ & $\begin{array}{l}3.1 \\
4.0\end{array}$ & $\begin{array}{l}1.2 \\
2.1\end{array}$ & $\begin{array}{l}1.2 \\
2.2\end{array}$ & $\begin{array}{l}1.4 \\
2.7\end{array}$ & $C R$ \\
\hline 10 & $32(\mathrm{~A} 2+)$ & $M$ & 349 & $\mathrm{CH}-\mathrm{B}$ & $\begin{array}{l}\text { nd } \\
1.8\end{array}$ & $\begin{array}{l}\text { nd } \\
1.3\end{array}$ & $\begin{array}{l}\text { nd } \\
1.4\end{array}$ & $\begin{array}{l}\text { nd } \\
2.3\end{array}$ & $C R$ \\
\hline 11 & $29(\mathrm{~A} 2+)$ & $M$ & 387 & $\mathrm{CH}-\mathrm{B}+\mathrm{AE} \S$ & $\begin{array}{l}0.3 \\
0.4\end{array}$ & $\begin{array}{l}0.3 \\
0.3\end{array}$ & $\begin{array}{l}0.1 \\
0.1\end{array}$ & $\begin{array}{l}0.1 \\
0.1\end{array}$ & PR§ \\
\hline 12 & $33(\mathrm{~A} 2+)$ & M & 807 & $\mathrm{CH}-\mathrm{B}+\mathrm{AE}$ & $\begin{array}{l}0.3 \\
0.7\end{array}$ & $\begin{array}{l}0.3 \\
0.6\end{array}$ & $\begin{array}{l}0.1 \\
0.2\end{array}$ & $\begin{array}{l}0.1 \\
0.2\end{array}$ & NR \\
\hline 13 & $26(\mathrm{~A} 2+)$ & $M$ & 1345 & $\mathrm{CH}-\mathrm{B}+\mathrm{AE}$ & $\begin{array}{l}\text { nd } \\
0.1\end{array}$ & $\begin{array}{l}\text { nd } \\
0.1\end{array}$ & $\begin{array}{l}\text { nd } \\
0.1\end{array}$ & $\begin{array}{l}\text { nd } \\
0.2\end{array}$ & NR \\
\hline 14 & $31(\mathrm{~A} 2+)$ & $\mathrm{F}$ & 900 & $\mathrm{CH}-\mathrm{B}+\mathrm{AE}$ & $\begin{array}{l}1.9 \\
3.5\end{array}$ & $\begin{array}{l}1.0 \\
1.3\end{array}$ & $\begin{array}{l}1.0 \\
1.4\end{array}$ & $\begin{array}{l}0.9 \\
1.1\end{array}$ & $C R$ \\
\hline $\begin{array}{l}\text { *All patie } \\
\text { †The hig } \\
\text { †Evaluat } \\
\text { §Evaluat } \\
\text { AE, acut } \\
\text { non-resp }\end{array}$ & $\begin{array}{l}\text { ients were } \\
\text { ghest level } \\
\text { ted at pretr } \\
\text { ted at the e } \\
\text { te exacerbo } \\
\text { conse; PR, }\end{array}$ & $\begin{array}{l}\text { LA-A2 } \\
\text { etected } \\
\text { atment } \\
\text { dd of th } \\
\text { tion; AL } \\
\text { artial } r\end{array}$ & $\begin{array}{l}\text { sitive. } \\
\text { ce entry } \\
\text { aseline vo } \\
\text { hird mont } \\
\text { alanine o } \\
\text { onse; nd }\end{array}$ & $\begin{array}{l}\text { llow up. } \\
\text { treatment. } \\
\text { transferase; } \\
\text { detected. }\end{array}$ & , chronic & atitis $B$ & $R, c c$ & lete $r$ & sponse; NR \\
\hline
\end{tabular}


Table 2 HLA-A2 restricted epitope peptides on hepatitis B virus (HBV) antigens used for cytotoxic T lymphocyte assay

\begin{tabular}{|c|c|c|c|c|c|c|c|c|c|c|c|}
\hline No & Amino acid residues & 1 & 2 & 3 & 4 & 5 & 6 & 7 & 8 & 9 & 10 \\
\hline 1 & Pre S2 152-161 & A & I & $\mathrm{L}$ & $S$ & $\mathrm{~K}$ & $T$ & G & $D$ & $P$ & $\mathrm{~V}$ \\
\hline 2 & HBs $177-185$ & V & $\mathrm{L}$ & $Q$ & $A$ & $G$ & $\mathrm{~F}$ & $\mathrm{~F}$ & 1 & $\mathrm{~L}$ & \\
\hline 3 & HBs 183-191 & $\mathrm{F}$ & L & $\mathrm{L}$ & $T$ & $\mathrm{R}$ & 1 & $\mathrm{~L}$ & $\mathrm{~T}$ & $\mathrm{~L}$ & \\
\hline 4 & HBs 204-212 & $\mathrm{F}$ & $\mathrm{L}$ & G & G & $\mathrm{T}$ & $\mathrm{R}$ & V & C & $\mathrm{L}$ & \\
\hline 5 & $\mathrm{HBs} 250-258$ & $\mathrm{~L}$ & $\mathrm{~L}$ & C & $\mathrm{L}$ & 1 & $\mathrm{~F}$ & $\mathrm{~L}$ & $\mathrm{~L}$ & V & \\
\hline 6 & HBs 260-269 & $\mathrm{L}$ & $\mathrm{L}$ & D & $Y$ & $Q$ & $G$ & $M$ & $\mathrm{~L}$ & $P$ & V \\
\hline 7 & $\mathrm{HBs} 335-343$ & W & $\mathrm{L}$ & $\mathrm{S}$ & $\mathrm{L}$ & $\mathrm{L}$ & V & $P$ & $\mathrm{~F}$ & V & \\
\hline 8 & HBs 348-357 & G & $\mathrm{L}$ & $\mathrm{S}$ & $P$ & $\mathrm{~T}$ & V & W & $\mathrm{L}$ & $\mathrm{S}$ & V \\
\hline 9 & $\mathrm{HBs} 370-379$ & $S$ & I & V & $S$ & $P$ & $\mathrm{~F}$ & I & $\mathrm{P}$ & $\mathrm{L}$ & $\mathrm{L}$ \\
\hline $10^{*}$ & Core 18-27 & $\mathrm{F}$ & $\mathrm{L}$ & $P$ & $\mathrm{~S}$ & $D$ & $\mathrm{~F}$ & $\mathrm{~F}$ & $P$ & $S$ & V \\
\hline 11 & Pol 575-583 & $\mathrm{F}$ & $L$ & $\mathrm{~L}$ & $\mathrm{~S}$ & $\mathrm{~L}$ & G & 1 & $\mathrm{H}$ & $\mathrm{L}$ & \\
\hline 12 & Pol 803-811 & $S$ & $\mathrm{~L}$ & $Y$ & A & $D$ & $S$ & $P$ & $\mathrm{~S}$ & V & \\
\hline $13^{*}$ & Pol 551-559 & Y & $M$ & D & $D$ & V & V & $\mathrm{L}$ & G & A & \\
\hline $14^{*}$ & Pol 551-559 & Y & V & $\mathrm{D}$ & $\mathrm{D}$ & V & V & $\mathrm{L}$ & G & A & \\
\hline $15^{*}$ & Pol 551-559 & Y & 1 & $D$ & $D$ & V & V & $\mathrm{L}$ & G & A & \\
\hline
\end{tabular}

studies were assessed before lamivudine therapy (pretherapy) and after three months of treatment.

\section{Synthetic peptides for T-cell analysis and synthesis of HLA-A2-peptide tetrameric complexes}

A total of 15 HLA-A2 restricted epitope peptides on HBV antigens (table 2 ) were used for the immunological studies. ${ }^{21-23}$ Peptides including: (a) HBcAg 18-27, FLPSDFFPSV; (b) wild-type YMDD motif nonapeptide YMDDVVLGA and its

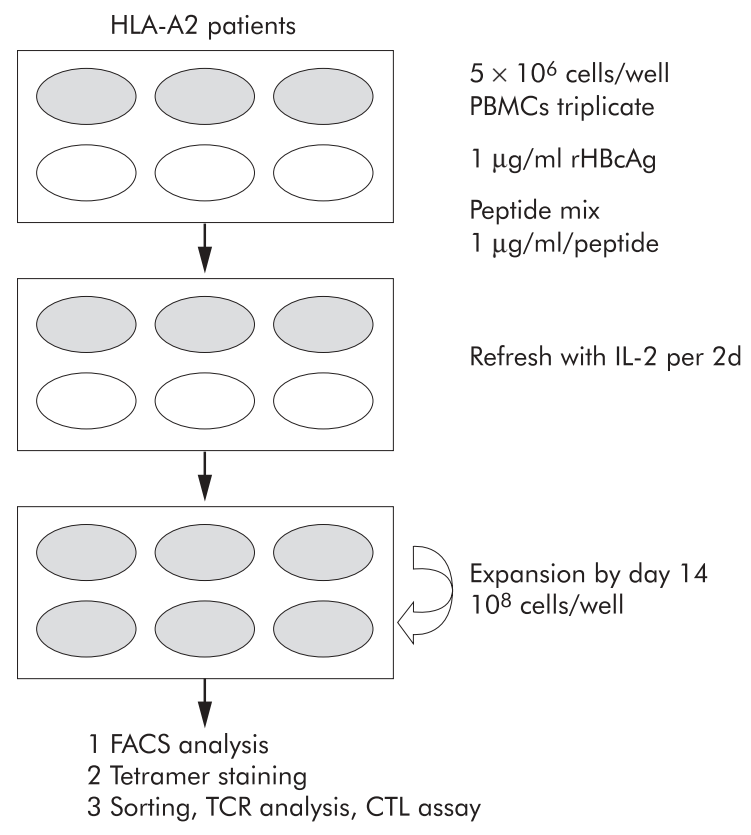

Figure 1 Protocol of the modified CTL response index of the peptide (CRl-p) culture method. On the first day of blood sampling, $5 \times 10^{6}$ peripheral blood mononuclear cells (PBMCs) in complete medium in triplicate cultures in a six well flat bottomed plate (Nunc, Roskilde, Denmark) with a mixture of the panel of peptides to be tested (each $1 \mu \mathrm{g} / \mathrm{ml}), 1 \mu \mathrm{g} / \mathrm{ml}$ recombinant hepatitis $\mathrm{B}$ core antigen $(\mathrm{rHBcAg})^{32}$, and $20 \mathrm{U} / \mathrm{ml}$ recombinant human interleukin 2 (rhll-2) were incubated at $37^{\circ} \mathrm{C}$ in a humidified $5 \% \mathrm{CO}_{2}$ incubator. On days $3,5,7,9,11$, and 13 , the culture medium was refreshed with $20 \mathrm{U} / \mathrm{ml}$ of rhll-2. Usually, the total number of cells could proliferate up to $3 \sim 5 \times 10^{7}$ cells on day 13 , and sometimes to $10^{8}$ cells by day 14 . Cells harvested on days 1415 were used for cell lytic assays and phenotypic study, with surface staining of MHC-A2-peptide tetrameric complexes. CTL, cytotoxic T lymphocyte; TCR, T cell receptor. mutants; (c)YVDD peptide YVDDVVLGA; and (d) YIDD peptide YIDDVVLGA were also used to construct HLA-A2peptide tetrameric complexes using a method described previously. ${ }^{24}$

\section{Modified CRI-p method}

As reported previously, the frequencies of tetramer staining CD8+ $\mathrm{T}$ cells in fresh peripheral blood mononuclear cells (PBMCs) are usually below $1 \%$ in freshly isolated PBMCs from the peripheral blood of both patients with hepatitis $\mathrm{B}^{25-27}$ and hepatitis C. ${ }^{28-31}$ To overcome this, the modified CRI-p method (fig 1), which can provide adequate cell numbers for FACS analysis in one experiment from single blood sampling, was adopted for semi quantitative determination of the relative strength of CTL activity against a panel of peptides. Briefly, freshly isolated PBMCs were plated in triplicate on six well plates $\left(5 \times 10^{6} /\right.$ well $)$ and cultured with $20 \mathrm{U} / \mathrm{ml}$ interleukin 2 (IL-2) and $1 \mu \mathrm{g} / \mathrm{ml}$ designated peptides. Fresh IL-2 was replaced every other day, and after 14 days of expansion, cell numbers could increase by 10-20-fold. The expanded cells were subjected to tetramer staining and functional assays.

\section{Cell lytic capacity of peptide and IL-2 expanded PBMCs}

Cytotoxicity assays were performed by coculturing effectors and target cells at ratios ranging from 10:1 to 40:1 in the nonradioactive enzyme immunoassay system CytoTox 96 (Promega, Madison, Wisconsin, USA) according to the manufacturer's instructions. In the experiments to test the cross reactivity of YMDD specific CTLs against other peptides, the E/T ratio was 20:1 to 5:1. Two types of effectors were used: one was the peptide specific cells expanded by the CRI-p method and the other was CD8+ T cells positively sorted from the peptide and IL-2 expanded population by the CRI-p method. Target cells included the HLA-A2 positive Epstein-Barr virus transformed B cell line (B-LCL) infected by HBV or exogenously pulsed with a panel of peptides. For HBV infection, B-LCL cells were transfected with the Simian virus 40 derived plasmid pSV2A-Neo- $(\mathrm{HBV})_{2}$ (a kind gift of Dr J-H Ou, University of Southern California, Los Angeles, California, USA) and selected with the neomycin analogue G418 by procedures described previously. ${ }^{32}$ B-LCL cells transfected with pSV2A-Neo-(HBV $)_{2}$ that could express all the $\mathrm{HBV}$ antigen proteins, including $\mathrm{HBsAg}, \mathrm{HBeAg}$, and HBcAg, were designated as HBV transfected B-LCL cells. HBV transfected B-LCL cells were used to serve as target cells for 
assessment of CTL recognition of endogenously presented HBV antigens. Mock transfected B-LCL cells were used as controls. In separate experiments, B-LCL cells exogenously pulsed with designated peptides of $1 \mu \mathrm{g} / \mathrm{ml}$ overnight were also used as target cells. Results were calculated as per cent specific cytotoxicity $=$ (experimental release - effector spontaneous release - target spontaneous release) / (target maximum release - target spontaneous release) $\times 100 \%$. Data for cell lytic analysis were expressed as modified CRI-p ( = mean of the per cent specific cytotoxicity of each of the triplicate cultures) and total modified CRI-p value ( = sum of all modified CRI-p of the tested panel of peptides).

\section{Cell lytic activity of FACS sorted peptide specific CD8 T cells}

Peptide specific CD8+ T cells were positively sorted from the cell population after peptide and IL-2 expansion in the modified CRI-p method. Cell lytic assays of these CTLs were performed as described above. However, because the number of sorted peptide specific CTLs was limited from single CRI-p culture, CTLs isolated and expanded from different CR patients were used for the assay against HBV infected targets or against cells pulsed with indicated epitope peptides. For example, YMDD specific CTLs sorted from patient No 3 were cocultured with B-LCL target cells transfected with HBV or pulsed with YMDD (see fig 3A). Likewise, YVDD specific CTLs from patient No 8 were assayed against B-LCL targets transfected with HBV or pulsed with YVDD (see fig 3B); YIDD specific CTLs from patient No 2 were cocultured with BLCL targets transfected with HBV or pulsed with YIDD (see fig 3C); HBcAg (18-27) specific CTLs from patient No 9 were assayed against B-LCL targets transfected with HBV or pulsed with $\mathrm{HBCAg}(18-27)$ (see fig 3D); and $\mathrm{HBcAg}(18-27)$ specific CTL cells from patient No 14 were tested against non-HLA$\mathrm{A} 2(+)$ targets transfected with $\mathrm{HBV}$ or pulsed with $\operatorname{HBcAg}(18-27)$ peptide (see fig 3E).
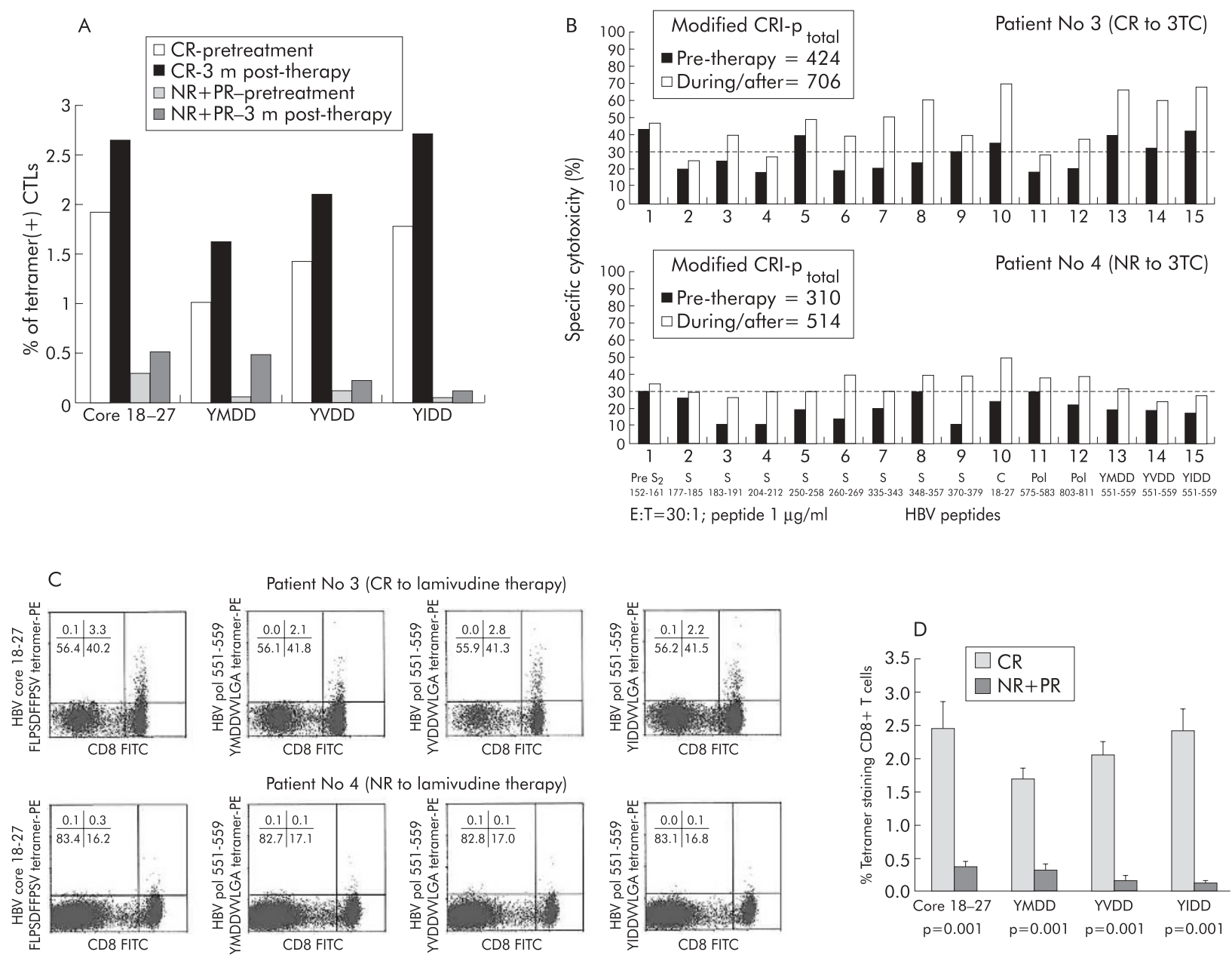

Figure 2 Cell lytic analysis of cells expanded using the CTL response index of the peptide (CRI-p) method. (A) Pretreatment and three months post treatment frequency of peptide specific CD8 T cells from four complete response (CR; patients 2, 8, 9, and 14) and four non-response (NR)+ partial response (PR) (patients 1, 6, 11, and 12) cases. Both pre- and post treatment levels of peptide specific CD8 T cell frequencies were higher in CR than in NR+PR patients. CTL, cytotoxic T lymphocyte. (B) Cell lytic activities of cells from patient No 3 (CR to lamivudine therapy) and patient No 4 (NR to lamivudine therapy) were assayed after in vitro expansion by the modified CRI-p method. Both cases had enhancement of killing capacity against various peptide epitopes of wild-type hepatitis B virus (HBV) antigens three months after treatment. Patient No 3 elicited more vigorous anti-YMDD motif killing activity than patient No 4. The broken line set at 30\% is the mean level (+3 SD) of the 11 non-HLA-A2 patients. Levels above this value were considered positive responses. (C) Phenotypic assay of peptide specific CD8 T cells. Representative fluorescence activated cell sorter analysis of tetramer assay in patient No 3 (top) and patient No 4 (bottom panel) using cells cultured from the modified CRI-p culture for surface staining. Compared with patient No 4, patient No 3 showed significantly higher percentages of tetramer staining for YMDD, YVDD, and YIDD as well as for HBV core 18-27 tetramers. (D) Frequencies of peptide specific CD8 T cells were higher in patients with CR than in those with NR/PR. Data for the frequencies of peptide specific CD8 T cells were pooled and compared between patients with CR (seven patients) and those with NR/PR (seven patients) (see table 1) using the Mann-Whitney U test. 


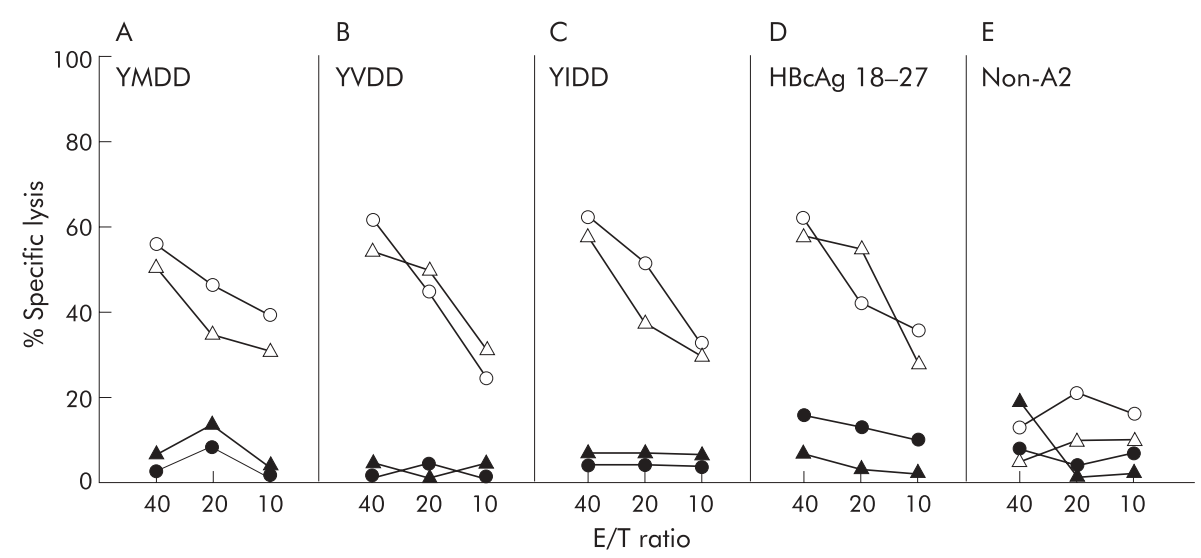

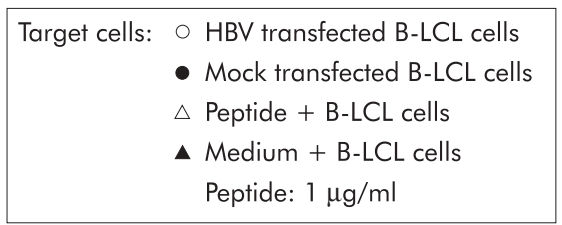

Figure 3 Cell lytic activities of peptide specific cytotoxic T lymphocyte (CTL) cells. Positively sorted peptide specific CD8 T cells after in vitro expansion by the modified CTL response index of the peptide (CRI-p) method were cocultured with hepatitis B virus (HBV) infected or peptide pulsed B-LCL target cells. CTLs including YMDD, YIDD, and YIDD tetramer stained CD8+ T cells sorted by fluorescence activated cell sorter analysis from different complete response patients were used as effector cells (see materials and methods) with three different effector/target cell ratios $(E / T$ ratio $=40,20$, and 10$)$. Target cells were either peptide pulsed, HBV transfected, or mock transfected B-LCL cells.

\section{FACS analysis}

For FACS analysis of peptide specific CD8+ T cells, cells cultured after expansion by the modified CRI-p method were processed on a Beckman Coulter EPICS Altra Hypersort System (Beckman Coulter, Inc., California, USA) and analysed by EXPO2 software (Beckman Coulter). The specificity of tetramers was confirmed using the method previously described..$^{24} 28$

\section{T cell receptor variable gene usages and junctional region sequence analysis}

YMDD, YVDD, YIDD, and HBV core 18-27 tetramer staining fractions of CD8+ T cells were positively sorted by FACS, respectively, after in vitro peptide and IL-2 expansion. TCR- $\alpha$ variable (AV) and $\beta$ variable (BV) gene usages were analysed individually by polymerase chain reaction (PCR) using $19 \mathrm{AV}$ and $21 \mathrm{BV}$ families of TCR primers, as described

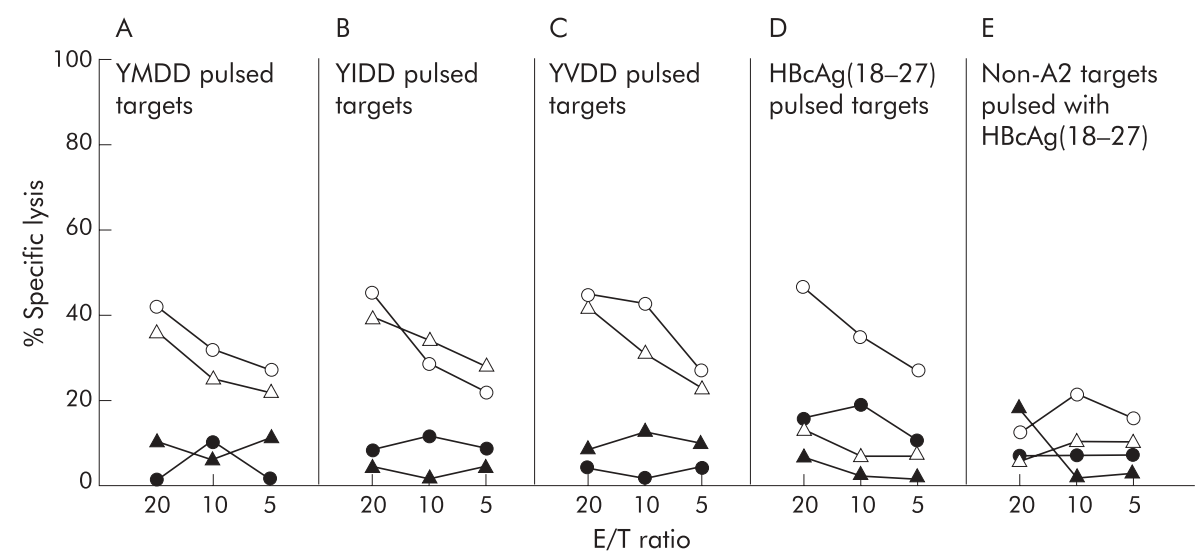

\begin{tabular}{|c|c|}
\hline Target cells: & $\begin{array}{l}\text { HBV transfected B-LCL cells } \\
\text { - Mock transfected B-LCL cells } \\
\triangle \text { Peptide }+B-L C L \text { cells } \\
\Delta \text { Medium + B-LCL cells } \\
\text { Peptide: } 1 \mu \mathrm{g} / \mathrm{ml}\end{array}$ \\
\hline
\end{tabular}

Figure 4 Cross reactivity of YMDD motif specific cytotoxic T lymphocytes (CTLs) against YIDD and YVDD but not hepatitis B core antigen (HBcAg) 1827. YMDD cell fraction sorted from patient No 3 after in vitro expansion also killed B-LCL cells pulsed with $1 \mu \mathrm{g} / \mathrm{ml}$ YIDD or YVDD peptide as efficiently as target cells pulsed with YMDD peptide (all induced approximately 35-40\% of specific target cell lysis at an effector/target cell (E/T) ratio of 20) but not with hepatitis B virus (HBV) core 18-27 peptide (A, B, and C v D). Non-HLA-A2 B-LCL target cells infected with HBV or pulsed with YMDD were used as controls (E). 
previously, ${ }^{34}{ }^{35}$ with $5^{\prime}$ and $3^{\prime}$ actin primers as internal controls. ${ }^{34}$ The authenticity of TCR primers was verified by examining TCR AV and BV expression on PBMCs stimulated with $1 \mu \mathrm{g} / \mathrm{ml}$ phytohaemagglutinin (PHA; Sigma, St Louis, Missouri, USA) for 72 hours. To evaluate junctional region sequences, PCR products were separated by electrophoresis on a $1.8 \%$ agarose gel, and DNA was purified and cloned into pT7 Blue T-Vector (Novagen, Madison, Wisconsin, USA). DNA sequences of at least three independent clones were obtained per PCR product from each cell fraction, and were sequenced using CEQ2000 DNA Analysis System (Beckman Coulter, Inc.). TCR gene usages of tetramer staining cells were assigned according to those previously described. ${ }^{36}{ }^{37}$

\section{Medium for cell culture}

Culture medium used in this study was RPMI 1640 supplemented with $5 \%$ heat inactivated human $\mathrm{AB}$ serum, $25 \mathrm{mM}$ HEPES, $2 \mathrm{mM}$ L-glutamine, 1\% sodium pyruvate, $0.05 \mathrm{mM}$ 2-mercaptoethanol, and antibiotics. All were purchased from Gibco Laboratories (Grand Island, New York, USA).

\section{Statistical analysis}

Statistical analysis was carried out with the SPSS for Windows, version 10.0. (SPSS Inc., Chicago, Illinois, USA). The Mann-Whitney $U$ test was used to compare unpaired data. Differences with a $\mathrm{p}$ value less than 0.05 were considered statistically significant.

\section{RESULTS}

Lamivudine responders showed a higher YMDD, YVDD, and YIDD specific CTL frequency and cytotoxicity activity after in vitro expansion

In total, seven CR, two PR, and five NR patients were enrolled and studied, among whom the frequency of the tetramer(+) CD8 T cells was determined in four CR, two PR, and two NR patients at both pretherapy and three months after treatment (table 1). As shown in fig $2 \mathrm{~A}$, the frequency of the tetramer(+) CD8 T cells was higher in the four CR patients than in the four PR+NR patients, both before initiation of therapy and three months after treatment. In the cytotoxicity assay of the cells expanded by the CRI-p method determined at three months after treatment, both lamivudine responders (for example, patient No 3) and non-responders (for example, patient 4) showed polyclonal cell lytic capacity to epitopes of different wild-type HBV antigens (fig 2B). The per cent specific cytotoxicity elicited by YMDD peptide and its mutants YVDD and YIDD was also higher in complete responders than in non-responders (fig 2B, columns 13$15)$. Furthermore, the frequencies of these peptide specific cells contained within the HLA-A2-tetramer-peptide (+) CD8 $\mathrm{T}$ cell population after in vitro expansion, as visualised by the phenotypic assay, were higher in CR (for example, patient No 3 ) than in NR (for example, patient No 4) patients (fig 2C) three months after treatment. There were only two PR patients in this series, which did not allow their $\mathrm{T}$ cell immunity to be analysed significantly. Nevertheless, when data from NR and PR patients were pooled together and compared with those of CR, the percentages of YMDD, YVDD, and YIDD tetramer staining CD8+ T cells after peptide/IL-2 expansion were significantly higher in the seven CR cases than in the five NR and two PR patients three months after lamivudine therapy (fig 2D, table 1).

\section{Enriched peptide specific CTLs from complete responders had effective capacities in killing of target cells}

To examine the functional activity of peptide specific CD8+ T cells, the peptide expanded population by the CRI-p method were positively sorted by FACS and cocultured with target cells, including HBV transfected B-LCL cells and B-LCL cells pulsed with $1 \mu \mathrm{g} / \mathrm{ml}$ of the corresponding peptides. Pulsing the target cells with a higher dose of peptides (for example, 4 and $2 \mu \mathrm{g} / \mathrm{ml}$ ) resulted in a higher percentage of killing (data not shown). However, as $1 \mu \mathrm{g} / \mathrm{ml}$ was used to expand the peptide specific $\mathrm{T}$ cells in the modified CRI-p method, this concentration was used throughout all the cell lytic experiments. Results revealed that YMDD specific CD8+ T cells
A

V $\alpha$ gene family

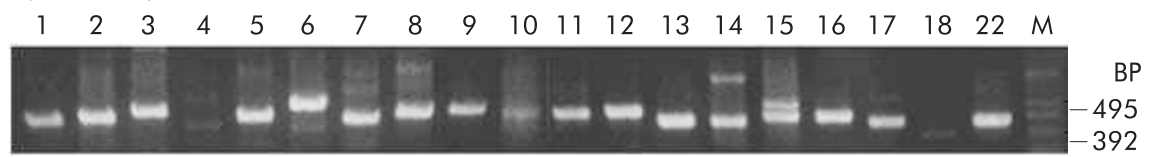

$\mathrm{V} \beta$ gene family

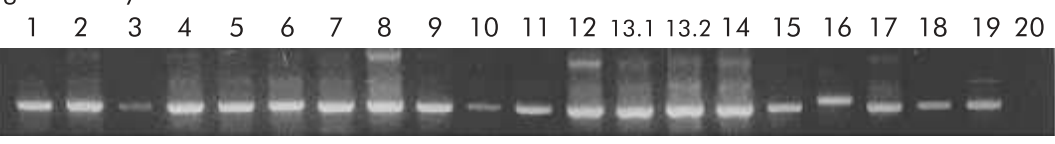

B

$V \alpha$ gene family

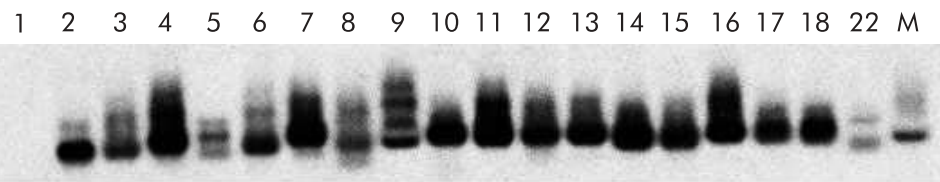

$\mathrm{V} \beta$ gene family

$\begin{array}{llllllllllllllllllllll}1 & 2 & 3 & 4 & 5 & 6 & 7 & 8 & 9 & 10 & 11 & 12 & 13.113 .2 & 14 & 15 & 16 & 17 & 18 & 19 & 20\end{array}$
Figure 5 Authenticity of T cell receptor $\alpha$ variable $(\mathrm{AV})$ and $\beta$ variable (BV) primers for polymerase chain reaction (PCR) analysis of variable gene usages in phytohaemagglutinin stimulated peripheral blood mononuclear cells. (A) Ethidium bromide staining of PCR products. (B) Autoradiography profile. The size of the amplified products using $5^{\prime} \mathrm{V} \alpha$ (or $\mathrm{V} \beta$ ? ? and $3^{\prime} \mathrm{C} \alpha$ (or $C \beta$ ) primers ranged from 320 to 520 base pairs (BP), and that of $5^{\prime}$ and $3^{\prime}$ actin primers was approximately 500 base pairs, which was used as the PCR control (data not shown). 


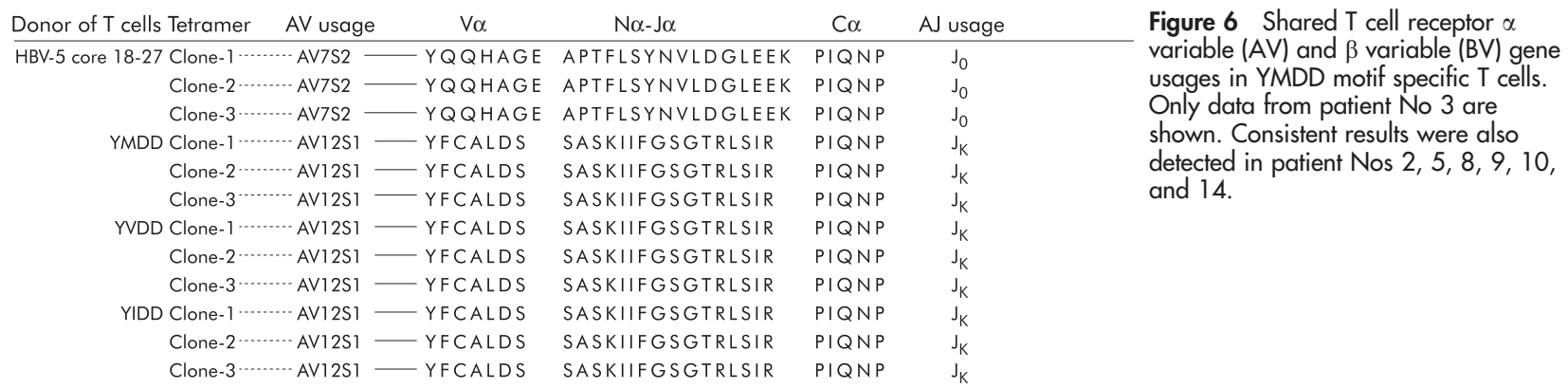

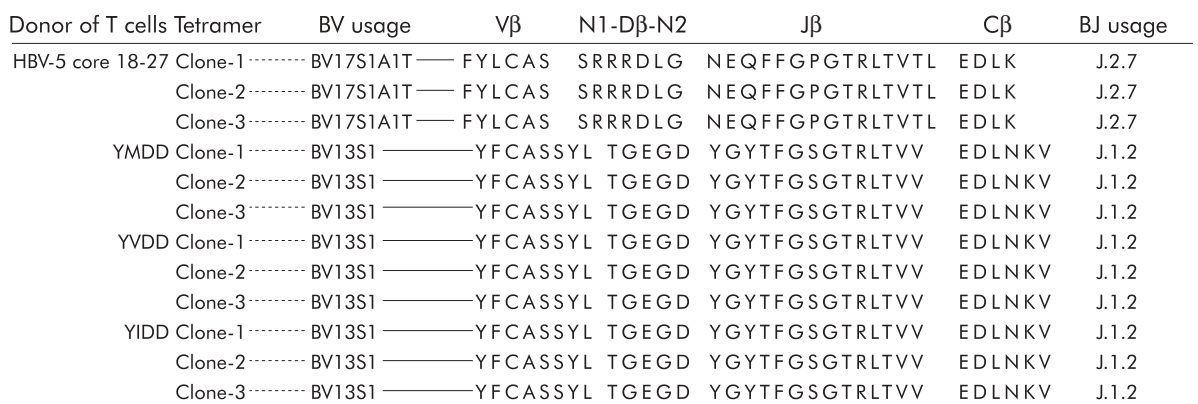

expanded and enriched by the CRI-p method from CR patients had effective capacities in killing the target cells endogenously expressing HBV antigens or exogenously pulsed with YMDD (fig 3A). Similar results were also noted for YVDD, YIDD, and HBcAg (18-27) specific CTLs (fig 3BD), indicating that these peptide specific CTLs are not only present in the peripheral blood of CR patients but are also able to kill HBV infected cells or any cells expressing relevant peptides in vitro.

YMDD specific CTLs cross reacted with YIDD and YVDD To determine if YMDD specific CTLs recognised their mutants, peptide/IL-2 expanded YMDD cells were positively sorted from patient No 3 and used as effector cells in coculture with HBV infected B-LCL or B-LCL cells pulsed separately with YIDD, YVDD, and HBCAg (18-27) peptides. As shown in fig 4, YMDD specific CD8+ cells could also kill B-LCL cells pulsed with YVDD or YIDD peptide as efficiently as those pulsed with YMDD peptide (approximately 35-40\% of specific target cell lysis at an E/T ratio of 20). No cross reactivity was noted against $\mathrm{HBcAg}(18-27)$ peptide (fig 4A, $\mathrm{B}, \mathrm{C} v \mathrm{D})$.

\section{YMDD specific T cells shared usages of TCR AV and BV} genes with YVDD and YIDD specific T cells

The primers of $19 \mathrm{~V} \alpha$ and $21 \mathrm{~V} \beta$ families used to amplify TCR $\mathrm{AV}$ and BV genes were verified in PHA stimulated PBMCs in both ethidium bromide staining (fig 5A) and autoradiography film (fig 5B). The V $\beta 20$ was very faint in the ethidium bromide staining gel but it could be clearly demonstrated on the autoradiography film. Results of TCR gene usage analysis of patient No 3 revealed that YMDD tetramer staining CD8+ T cells shared AV12S1 and BV13S1 in TCR AV and BV gene usages, respectively, with YVDD and YIDD tetramer staining CD8+T cells but not with HBV core 18-27 tetramer staining CD8+T cells in which AV7S2 and BVI7SlAlT were used, respectively (fig 6). Consistent results were also noted in patient Nos 2, 5, 9, and 10 with CR to lamivudine therapy (that is, all YMDD specific CTLs shared TCR AV and BV gene usages with YIDD and YVDD specific CTLs but not with HBcAg 18-27 specific CTLs; data not shown). These results together with data from CTL assays (that is, figs 3,4 ) further confirmed that the anti-YMDD CTL response was cross reactive against YVDD and YIDD.

Frequency of A2 tetramer (+) anti-(YIDD+ YVDD) CD8+ $T$ cells after in vitro expansion is higher than YMDD and $\mathrm{HBCAg}(18-27)$ specific CD8+ T cells after lamivudine therapy in $C R$ patients

When assayed three months after treatment, the frequency of anti-mutant (YIDD+YVDD) CD8+ T cells in patient No 2 (CR to treatment) was higher than that of YMDD and HBV core (18-27) tetramer $(+)$ CD8 $\mathrm{T}$ cells after in vitro expansion (fig 7A). Such results were also noted in most other CR patients, such as patient No 3, 5, 8, 9, 10, and 14 (table 1). Overall, these CR patients had 2-3-fold higher numbers of mutant (YVDD+YIDD) specific CD8+ $\mathrm{T}$ cells than those of YMDD specific CD8+ T cells (fig 7B).

\section{DISCUSSION}

It has been reported that lamivudine can restore $\mathrm{T}$ cell responsiveness to several different CTL and $\mathrm{T}$ helper cell epitopes. ${ }^{22}{ }^{38}$ We have also demonstrated that activation of Thl immunity is a common immune mechanism for the successful treatment of $\mathrm{HBV}$ and HCV infections. ${ }^{28}$ The results from the present study have shown that in patients who had $\mathrm{T}$ cell immunity analysed after in vitro expansion both before and after lamivudine treatment (that is, four CR and four PR+NR cases), CR patients had a higher frequency of tetramer staining CD8+ $\mathrm{T}$ cells than non-CR (PR+NR) patients (table 1, fig 2A), including YMDD, YVDD, YIDD, and HBcAg(18-27) specific CD8 $\mathrm{T}$ cells. When assayed three months post therapy, all seven CR patients consistently had polyclonal activation of anti-wild-type HBV immune responses, including HBcAg 18-27, manifested by the simultaneous increase in the per cent specific cytotoxicity of peptide expanded cells against different wild-type HBV specific peptide epitopes (fig 2B). These seven CR patients also exhibited significantly higher anti-YMDD and antimutant (-YVDD and -YIDD) cell lytic capacity compared with that of non-responders or partial responders (fig 2B, table 1). Peptide/IL-2 expanded YMDD and mutant specific CD8+ T cells also had detectable killing ability (fig 3 ). In agreement with the functional assay, the phenotypic studies assayed 

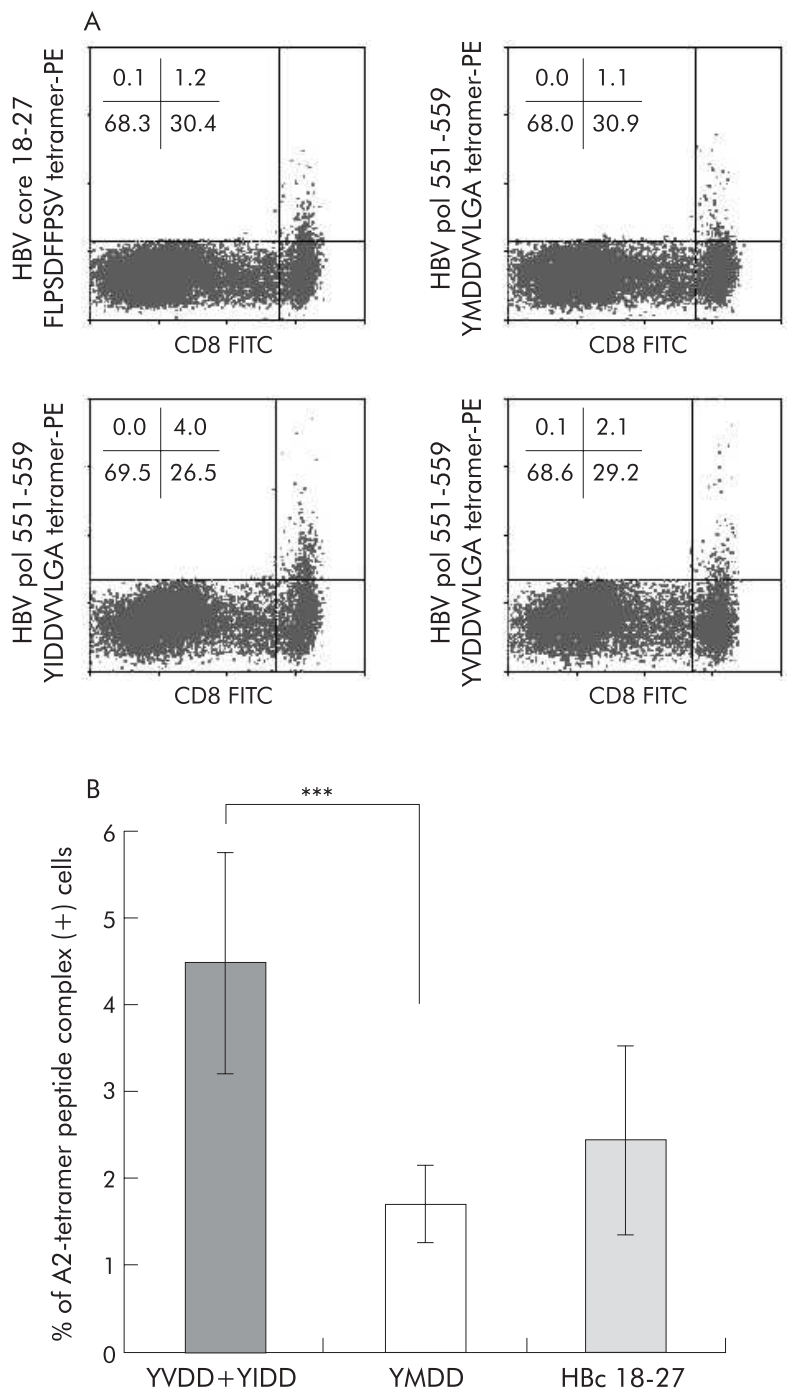

Figure 7 Frequency of YIDD+YVDD specific cytotoxic T lymphocytes (CTLs) was higher than that of YMDD specific CTLs in complete response (CR) patients. Total frequency of YMDD mutant (that is, YIDD+YVDD) tetramer stained CD8+ T cells after expansion using the modified CTL response index of the peptide (CRI-p) method from patient No 2 was compared with that of $Y M D D$ specific and hepatitis $B$ core antigen $(\mathrm{HBC}$ 18-27) specific CTLs (A) three months after therapy. Before therapy, the frequency of YIDD was $2.9 \%$ (table 1) after in vitro expansion. Overall, CR patients had a significantly higher YIDD and YVDD specific CTL frequency than YMDD specific cells (B). ${ }^{* * *} p=0.001$, Mann-Whitney $\mathrm{U}$ test.

three months after treatment also revealed that the frequencies of CTLs specific for YMDD, YIDD, and YVDD correlated with treatment outcome (fig 2C, D, table 1). Clinical observations have shown that in one-fifth to half of patients who responded initially to lamivudine monotherapy, the response was not sustained on lamivudine withdrawal. Risk factors associated with this low sustainability include low pretreatment levels of serum ALT and lack of additional use of interferon, ${ }^{20}{ }^{39}$ suggesting that there is an inadequate HBV specific immune response at the end of therapy. Moreover, lamivudine resistant mutation has frequently been detected after long term therapy which has been regarded as one of the major causes for treatment failure. ${ }^{14}$ Our present study suggests that in addition to wild-type HBV specific antigens, generation of effective CTLs against YMDD and its mutants correlates with the clinical results, implying that these antimutant CTLs may also contribute to clearance of emerging mutant viruses and successful response to lamivudine treatment.

In the crossover experiments, anti-YMDD CTLs also recognised and lysed target cells coated with YVDD and YIDD peptides (fig 4). Moreover, they shared TCR gene usages with YVDD and YIDD specific CTLs (fig 6), indicating that these cells might be derived from the same CTL precursors with a different capacity in binding the MHCA2-peptide complexes. The mechanism for such "cross recognition" is unclear. It has been shown that in patients with acute HBV infection, MHC binding supermotif derived peptides may predict broadly cross reactive CTL responses. ${ }^{40}$ In animal models, amino acid replacement in the second MHC-A2 binding position of peptide may also enhance in vitro potency and in vivo immunogenicity of a CTL epitope from HCV core protein in transgenic $\mathrm{A} 2 \mathrm{~Kb}$ mice. ${ }^{41}$ Indeed, the lamivudine associated mutation of the polymerase 551-559 epitope is located at position 552 of the peptide, which corresponds to position 2 of the MHC-A2 peptide epitope, a position important for anchoring to MHC class I molecules but not for T cell interaction. Therefore, cross recognition of YMDD specific T cells against YVDD and YIDD is not totally unexpected. Nevertheless, our data confirmed that apart from acute infection, cross reactivity of YMDD specific CTLS against its mutants is also present in patients with $\mathrm{CH}-\mathrm{B}$ infection. It is likely that in patients with a CR, substitution of different amino acids at position 2 of YMDD (for example, YIDD and YVDD) actually enhances peptide binding affinity on MHC class I molecules, which subsequently increases the efficacy of antigen presentation without reducing TCR recognition capacity.

The reason for the lack of response in our NR patients is not immediately clear. Lamivudine requires intracellular metabolism to its active form, 5'-triphosphate, 3TC-5'triphosphate (3TCTP), to inhibit the replication of HBV DNA. ${ }^{42}$ Further studies are needed to determine whether NR patients are unable to phosphorylate lamivudine. However, amino acid substitutions within a defined epitope may also result in reducing or eliminating, instead of augmenting, MHC class I binding and/or failed recognition by antiviral CTLs, as has been noted in selected patients with $\mathrm{HBV}^{43}$ and $\mathrm{HCV}^{44}$ infection. It is therefore likely that the unsatisfactory CTL responses to lamivudine therapy in our non-responders or partial responders may be due to decreased, in contrast with enhanced, peptide-MHC binding and impaired antigen presentation of YVDD and YIDD after single nucleotide mutation. These issues deserve further investigation.

Drug resistant mutant viruses often emerge after current monotherapy with nucleoside analogues. By highly sensitive diagnostic assays, rtM552I/V mutant HBV can be detected as early as three months post therapy. ${ }^{45}$ Thus far, it is still an issue of debate if lamivudine resistant mutants actually exist before therapy or whether lamivudine per se enforces wildtype virus for evolutionary mutation. Clinically, discontinuation of lamivudine therapy usually results in disappearance of rtM552I/V mutations, accompanied by an outgrowth of wildtype HBV. Moreover, readministration of lamivudine usually results in a prompt re-emergence of resistant strains ${ }^{46}$ It is thus likely that mutant viruses may well pre-exist in the hosts prior to treatment, and administration of lamivudine therapy rapidly suppress the wild-type HBV and selects resistant mutants to growth. Recently, Kobayashi and colleagues $^{47}$ detected YMDD motif mutations in some lamivudine untreated asymptomatic HBV carriers, including mixed infections of YMDD+YIDD and YMDD+YIDD+YVDD. Our data also showed that before initiation of lamivudine treatment, patients with CR to treatment already had a higher frequency of YIDD and YVDD tetramer stained CTL cells than NR+PR patients (table 1, fig 2A) assayed after in 
vitro expansion, as well as relatively more potent anti-YIDD and -YVDD CTL activity three months after therapy (table 1, fig 7A, B). These findings further point to the likelihood that mutant viruses may pre-exist, at least in these selected patients, so that pre-existing memory $\mathrm{T}$ cells respond to treatment and proliferate, leading to a high level of functional anti-mutant CTL activity.

In conclusion, our data demonstrated both phenotypically and functionally the presence of significantly more potent YMDD specific CTLs cross recognising other mutant epitopes in patients with $\mathrm{CH}-\mathrm{B}$ infection with a complete response to lamivudine therapy. The reason why patients with PR or NR to therapy had a lower frequency and ineffective anti-mutant CTL immunity is still unknown. Inability of TCR recognition of mutant peptides, as described above, may be one of the contributing factors. Other determinants such as HBV genotype, inability to phosphorylate lamivudine, age of patients, duration of treatment, and population differences may also play a role. ${ }^{32042} 48-51$ In our preliminary follow up study, two of our NR patients developed dual genotype infection (data not shown). Nevertheless, our study suggest that in addition to those against immunogenic peptide epitopes of wild-type HBV, activation of CTL responses to YMDD, YVDD, and YIDD correlates with a sustained successful response to lamivudine therapy, at least in HLAA2 patients. Cross reactivity of YMDD specific CTLs against its mutants may further control the growth of mutant viruses. Similar mechanisms may also contribute to successful response in non- HLA-A2 individuals. Whether or not YMDD specific CTLs could also recognise other newly discovered mutants (for example, YSDD) ${ }^{52}$ that may also result in treatment failure remains to be elucidated.

\section{ACKNOWLEDGEMENTS}

We are grateful to Miss Chin-Li Lu, MS, Department of Medical Research, Chi-Mei Medical Centre, Tainan, Taiwan, for statistical analysis of the data.

This work was supported in part by grants NSC 91-2314-B-384-006MH and 91-2314-B-384-007 MH from the National Science Council, Taipei, Taiwan, and the Chi-Mei Foundation CMFHT 9102, Tainan, Taiwan, to S-LT.

\section{Authors' affiliations}

C-L Lin, Department of Surgery, Hong Kong University Medical Centre, Queen Mary Hospital, Hong Kong

S-L Tsai, Liver Research Unit, Department of Medical Research, Chi-Mei Medical Centre, Tainan, Taiwan

T-H Lee, R-N Chien, Y-F Liaw, Liver Research Unit, Chang-Gung

Memorial Hospital, Chang Gung University College of Medicine, Taipei, Taiwan

S-K Liao, Graduate Institute of Clinical Medical Sciences, Chang Gung University College of Medicine, Taipei, Taiwan

Conflict of interest: None declared.

\section{REFERENCES}

1 Lai CL, Chien RH, Leung NWY, et al. A one-year trial of lamivudine for chronic hepatitis B. N Engl J Med 1998;339:61-8.

2 Jarvis B, Faulds D. Lamivudine: a review of its therapeutic potential in chronic hepatitis B. Drugs 1999;58:101-41

3 Dienstag JL, Schiff ER, Wright TL, et al. Lamivudine as initial treatment for chronic hepatitis B. N Engl J Med 1999;341:1256-63.

4 Liaw YF, Leung NWY, Chang $\Pi$, et al. Effects of extended lamivudine therapy in Asian patients with chronic hepatitis B. Gastroenterology 2000; 119:172-80.

5 Jonas MM, Kelley DA, Mizerski J, et al. Clinical trial of lamivudine in children with chronic hepatitis B. N Engl J Med 2002;346:1706-13.

6 Doong SL, Tsai CH, Schinazi RF, et al. Inhibition of the replication of hepatitis $B$ virus in vitro by $2^{\prime}, 3^{\prime}$-dideoxy-3'-thiacytidine and related analogues. Proc Natl Acad Sci U S A 1991;88:8495-99.

7 Dienstag JL, Perillo RP, Schiff ER, et al. A preliminary trial of lamivudine for chronic hepatitis B infection. N Engl J Med 1995;333:1657-61.

8 Mckenzie R, Fried MW, Sallie R, et al. Hepatic failure and lactic acidosis due to fialuridine (FIAU), an investigational nucleoside analogue for chronic hepatitis. N Engl J Med 1995;333:1099-105.
9 Leung NWY, Lai CL, Chang TT, et al. Extended lamivudine treatment in patients with chronic hepatitis $B$ enhances hepatitis $B$ e antigen seroconversion rates: results after 3 years of therapy. Hepatology 2001;33:1527-32.

10 Chang TT, Lai CL, Liaw YF, Guan R, et al. Incremental increases in $\mathrm{HBeAg}$ seroconversion and continued ALT normalization in Asian chronic HBV patients treated with lamivudine for four years. Antiviral Ther 2000;5(suppl 1):44.

11 Bartholomew M, Jansen RW, Jeffers $U$, et al. Hepatitis-B-virus resistance to lamivudine given for recurrent infection after orthotopic liver transplatation. Lancet 1997;349:3-4.

12 Allen MI, Deslauriers M, Andrews CW, et al. Identification and characterization of mutations in hepatitis $B$ virus resistant to lamivudine. Hepatology 1998;27:1670-7.

13 Hadziyannis SJ, Papatheodoridis GV, Dimou E, et al. Efficacy of long-term lamivudine monotherapy in patients with hepatitis $B$ e antigen-negative chronic hepatitis B. Hepatology 2000;32:847-51.

14 Liaw YF, Chien RN, Yeh CT, et al. Acute exacerbation and hepatitis B virus clearance after emergence of YMDD motif mutation during lamivudine therapy. Hepatology 1999;30:567-72.

15 Kim JW, Lee HS, Woo GH, et al. Fatal submassive hepatic necrosis associated with tyrosine-methionine-aspartate-aspartate motif mutation of hepatitis $B$ virus after long-term lamivudine therapy. Clin Infect Dis 2001;33:403-5.

16 Bock CT, Tillmann HL, Torresi J, et al. Selection of hepatitis B virus polymerase mutants with enhanced replication by lamivudine treatment after liver transplation. Gastroenterology 2002;122:264-73.

17 Honkoop P, Niesters HGM, Man RA, et al. Lamivudine resistance in immunocompetent chronic hepatitis $B$; Incidence and patterns. J Hepatol 1997;26:1393-5.

18 Wainberg MA, Drosopoulos WC, Salomon H, et al. Enhanced fidelity of 3TCselected mutant HIV-1 reverse transcriptase. Science 1996;271:1282-5.

19 Omata M. Treatment of chronic hepatitis B infection. N Engl J Med 1998:339:114-15.

20 Chien RN, Yeh CT, Tsai SL, et al. The determinants for sustained $\mathrm{HBeAg}$ response to lamivudine therapy. Hepatology 2003;38:1267-73.

21 Rehermann B, Fowler P, Sidney J, et al. The cytotoxic T lymphocyte response to multiple hepatitis $B$ virus polymerase epitopes during and after acute viral hepatitis. J Exp Med 1995;181:1047-58.

22 Boni C, Bertoletti A, Penna A, et al. Lamivudine treatment can restore T cell responsiveness in chronic hepatitis B. J Clin Invest 1998;102:968-75.

23 Chisari FV, Ferrari C. Hepatitis B virus immunopathogenesis. Annu Rev Immunol 1995;13:29-60.

24 Lee TH, Chuang YL, Tsai SL, et al. Effects of lamivudine on the hepatitis B virus specific CD8+ cytotoxic T lymphocyte response via peptide-MHC tetrameric complexes assay. Lett Pept Sci 2002;8:179-85.

25 Maini MK, Boni C, Ogg GS, et al. Direct ex vivo analysis of hepatitis B virusspecific CD8+ T cells associated with the control of infection. Gastroenterology 1999;117:1386-96.

26 Maini MK, Boni C, Lee CK, et al. The role of virus-specific CD8+ cell in liver damage and viral control during persistent hepatitis $B$ virus infection. J Exp Med 2000;191:1269-80.

27 Reignat S, Webster GJM, Brown D, et al. Escaping high viral load exhaustion: CD8 cells with altered tetramer binding in chronic hepatitis $B$ virus infection. J Exp Med 2002;195:1089-101

28 Tsai SL, Sheen IS, Chien RN, et al. Activation of Thl immunity is a common immune mechanism for the successful treatment of hepatitis $B$ and $C$ : tetramer assay and therapeutic implications. J Biomed Sci 2003;10:120-35.

29 He X-S, Rehermann B, López-Labrador FX, et al. Quantitative analysis of hepatitis $C$ virus-specific CD8+ T cells in peripheral blood and liver using peptide-MHC tetramers. Proc Natl Acad Sci U S A 1999;96:5692-7.

30 Laver GM, Nguyen TN, Day CL, et al. Human immunodeficiency virus type 1hepatitis $C$ virus coinfection: intraindividual comparison of cellular immune responses against two persistent viruses. J Virol 2002;76:2817-26.

31 Laver GM, Ouchi K, Chung RT, et al. Comprehensive analysis of CD8 ${ }^{+}$-T-cell responses against hepatitis $C$ virus reveals multiple unpredicted specificities. J Virol 2002;76:6104-13.

32 Yeh CT, Liaw YF, Ou JH. The arginine-rich domain of hepatitis B virus precore and core protein contains a signal for nuclear transport. J Virol 1990;64:6141-7.

33 Tsai SL, Chen MH, Yeh CT, et al. Purification and characterization of a naturally processed hepatitis $B$ virus peptide recognized by CD8+ cytotoxic $T$ lymphocytes. J Clin Invest 1996;97:577-84.

34 Tsai SL, Chen PJ, Liao TH, et al. Characterization of T cell clones specific to a determinant of hepatitis $B$ virus core and e antigens in chronic type $B$ hepatitis: implication for T cell mechanism of HBV immunopathogenesis. J Biomed Sci 1994; 1:105-18.

35 Tsai SL, Lai MY, Chen DS. Analysis of rearranged T cell receptor (TCR) V $\beta$ transcripts in livers of primary biliary cirrhosis: preferential $V \beta$ usage suggests antigen-driven selection. Clin Exp Immunol 1996;103:99-104

36 Toyonaga B, Mak TW. Genes of the T- cell antigen receptor in normal and malignant T cells. Annu Rev Immunol 1987;5:585-620.

37 Arden B, Clark SP, Kabelitz D, et al. Human T-cell receptor variable gene segment families. Immunogenetics 1995;42:455-500.

38 Boni C, Penna A, Ogg GS, et al. Lamivudine treatment can overcome cytotoxic T-cell hyporesponsiveness in chronic hepatitis $B$ : new perspectives for immune therapy. Hepatology 2001;33:963-71.

39 Dienstag JL, Cianciara J, Karayalcin S, et al. Durability of serologic response after lamivudine treatment of chronic hepatitis B. Hepatology 2003;37:748-55 
40 Bertoni R, Sidney J, Fowler P, et al. Human histocompatibility leucocyte antigen-binding supermotifs predict broadly cross-reactive cytotoxic $T$ lymphocyte respondes in patients with acute hepatitis. J Clin Invest 1997:100:503-13.

41 Sarobe $\mathbf{P}$, Pendleton CD, Akatsuka T, et al. Enhanced in vitro potency and in vivo immunogenicity of a CTL epitope from hepatitis $C$ virus core protein following amino acid replacement at secondary HLA-A2.1 binding position. J Clin Invest 1998;102:1239-48.

42 Shaw T, Mok SS, Locarnini SA. Inhibition of hepatitis B virus DNA polymerase by enantiomers of penciclovir triphosphate and metabolic basis for selective inhibition of HBV replication by penciclovir. Hepatology 1996;24:996-1002.

43 Bertoletti A, Sette A, Chisari FV, et al. Natural variants of cytotoxic epitopes are T-cell receptor antagonists for antiviral cytotoxic T cells. Nature 1994:369:407-10.

44 Tsai SL, Chen YM, Chen MH, et al. Hepatitis $C$ virus variants circumventing cytotoxic T lymphocyte activity as a mechanism of chronicity. Gastroenterology 1998;115:954-66.

45 Paik YH, Chung HY, Ryu WS, et al. Emergence of YMDD motif mutant of hepatitis B virus during short-term lamivudine therapy in South Korea. J Hepatol 2001;35:92-8.
46 Nafa S, Ahmed S, Chayama D, et al. Emergence and takeover of YMDD motif mutant hepatitis $B$ virus during long-term lamivudine therapy and re-takeover by wild type after cessation of therapy. Hepatology 1998;27:1711-16.

47 Kobayashi S, Ide T, Sata H. Detection of YMDD mutations in some lamivudine-untreated asymptomatic hepatitis B virus carriers. J Hepatol $2001 ; 34: 584-6$

48 Dienstag JL, Schiff ER, Mitchell M, et al. Extended lamivudine retreatment for chronic hepatitis B:maintenance of viral suppression after discontinuation of therapy. Hepatology 1999;30:1082-7.

49 Song BC, Suh DJ, Lee HC, et al. Hepatitis B e antigen seroconversion after lamivudine therapy is not durable in patients with chronic hepatitis $B$ in Korea. Hepatology 2000;32:803-6.

50 Lee KM, Cho SW, Kim SW, et al. Effect of virological response on posttreatment durability of lamivudine-induced $\mathrm{HBeAg}$ seroconversion. J Viral Hepat 2002;9:208-12.

$51 \mathrm{Kao} \mathrm{JH}$. Hepatitis B viral genotypes: Clinical relevance and molecular characteristics. J Gastroenterol Hepatol 2002;17:643-50.

52 Bozdayi AM, Uzunalimoglu O, Turkyilmaz AR, et al. YSDD: a novel mutation in HBV DNA polymerase confers clinical resistance to lamivudine. J Viral Hepat 2003; 10:256-65.

\section{EDITOR'S QUIZ: GI SNAPSHOT}

\section{Chronic diarrhoea after allogenic bone marrow transplantation}

\section{Clinical presentation}

A chronic myeloid leukaemia was diagnosed in a 25 year old woman, and nine months later she developed an acute transformation. After conditioning chemotherapy without total body irradiation, she received an allogenic bone marrow transplantation (BMT). Post transplant complications included pulmonary infections and acute graft versus host disease (GVHD) affecting the skin (grade I) and the liver, with a rapid response to corticosteroids and cyclosporin. In the following year, she developed diabetes, cataract, and femoral osteonecrosis, and the treatment was tapered. Chronic diarrhoea progressively developed with weight loss of $20 \mathrm{~kg}$. Stool weight was of $600 \mathrm{~g} /$ day with steatorrhoea of $45 \mathrm{~g} /$ day. The D-xylose test was normal and the Schilling test showed partial B12 malabsorption. Oesogastroduodenoscopy with biopsies was normal. Ileocolonoscopy was macroscopically normal but biopsies of the ileum showed signs of attenuated GVHD. A computed tomography scan of the abdomen was performed (fig 1B) and compared with a previous scan, performed before BMT (fig lA).

\section{Question}

What do theses scans (fig 1A, B) show?

See page 174 for answer

This case is submitted by:

B Radu, M Allez, J-M Gornet, M Lemann Service de Gastroentérologie, Hôpital Saint-Louis, Paris, France

G Socie, E Gluckman Service de Greffe de Moelle, Hôpital Saint-Louis, Paris, France

A-M Zagdanski

Service de Radiologie, Hôpital Saint-Louis, Paris, France

Correspondence to: Professor M Lémann, Service de Gastroentérologie, Hôpital Saint-Louis, 1 Avenue Claude Vellefaux, F75010, Paris, France, marc@lemann.com

doi: $10.1136 /$ gut.2004.041335
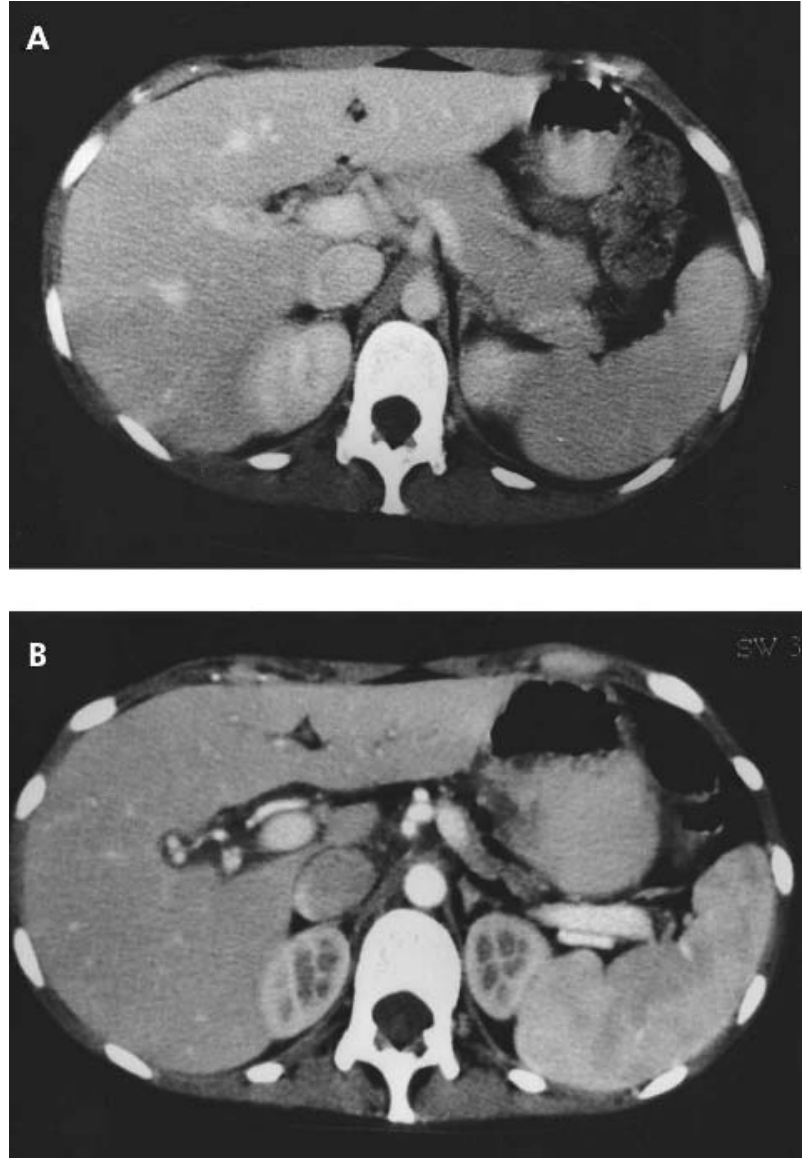

Figure 1 Computed tomography scan of the abdomen before $(A)$ and after (B) bone marrow transplantation. 